\title{
David Oliver: NHS continuing care confusion
}

\author{
David Oliver consultant in geriatrics and acute general medicine
}

Berkshire

Every year the NHS Ombudsman receives hundreds of complaints about assessment, funding, and provision of free NHS continuing healthcare (CHC) for people with complex health needs or near the end of life. ${ }^{1}$ The National Audit Office published a major report in 2017, partly in response to numerous complaints. ${ }^{2}$ In 2018 the Public Accounts Committee published another, also looking at future threats to funding from targeted savings drives by clinical commissioning groups (CCGs). ${ }^{3}$

In June this year the BBC reported on the personal impact felt by already distressed people struggling to access such complex care, particularly in getting CCGs to agree funding. ${ }^{4}$ This followed reports of thousands of people dying while funding decisions were delayed. ${ }^{5}$

It's no coincidence that both the ombudsman's office ${ }^{6}$ and NHS England ${ }^{7}$ have public information on processes, entitlements, complaints, and appeals_-or that so many charitable advocacy groups and law firms offer guidance and support for patients battling or navigating the system. ${ }^{8-10}$

Funding and provision of free $\mathrm{CHC}$ reflects a legacy of historical policy decisions to devolve responsibility for adult social care-such as personal homecare and long term residential care, based on eligibility criteria-to local government. ${ }^{11}$ Means testing often leaves service users and their families bearing financial costs, and, despite entitlements for assessment and support enshrined in the Care Act 2014, ${ }^{12}$ these people can be left to navigate the system without much support. ${ }^{13}$

The problems with $\mathrm{CHC}$ are the less discussed $\mathrm{B}$ side to the serially broken record of social care. But they're not negligible. Around $160000 \mathrm{CHC}$ applications are made each year, and the NHS spends around $£ 3$ bn a year (about $3 \%$ of its budget) on the successful ones. ${ }^{23}$

Earlier in my career, different demographics meant that we had nowhere near today's numbers of people with very complex, unpredictable, or unstable needs requiring a mixture of highly skilled clinical and personal care. We also had more hospital beds, with less of an imperative to reduce very long stays and less focus on supporting end-of-life care outside hospital. By rights we should have expanded $\mathrm{CHC}$ funding and provision to match these changes, not cut and restricted them.
We've had several years of flat NHS funding, growing deficits and pressures on providers and service commissioners, and serial deep cuts to social care funding since 2010, leaving far fewer people with statutory support. ${ }^{1516}$ In such a perfect storm, $\mathrm{CHC}$ funding has become a battleground between local government and its NHS partners, leaving the people who need these services caught in the crossfire.

There are detailed national eligibility criteria and assessment processes for $\mathrm{CHC} .{ }^{17}$ It's a very high threshold to meet, even when assessment processes are applied consistently and objectively by trained assessors. Yet the National Audit Office ${ }^{2}$ and the Public Accounts Committee ${ }^{3}$ reported major regional variation in how these criteria are applied, how long decisions take, and CCGs' ability to organise care first and argue about funding later. When $\mathrm{CHC}$ funding is denied, the serious financial consequences for patients and carers, and their inability to access support, cause anxiety and anger and can leave people stranded in hospital, until they die or negotiate a move to long term residential care. ${ }^{18}$

I'm sure that being an official continuing care assessor or panel chair is tough, given the emotionally charged and financially critical nature of the decisions. Stereotypes of uncaring bureaucrats motivated only by savings are probably unfair. With formal complaints or news reports about individual cases, it's hard for professionals to challenge and correct apparent inaccuracies from their side. And every decision to fund one person's care has knock-on effects for someone else. These necessary decisions won't please the people who get turned down-even those who don't come close to meeting the official eligibility criteria.

We haven't got CHC right, and the situation may worsen if it isn't given at least the same attention as social care funding. As the latter has been repeatedly ducked and delayed, I'm not holding out much hope for the people affected.

Competing interests: See www.bmj.com/about-bmj/freelance-contributors. Provenance and peer review: Commissioned; not externally peer reviewed. 
1 Parliamentary and Health Service Ombudsman. The ombudsman's annual report and accounts 2017-2018. $18 \mathrm{Jul}$ 2018. https://www.ombudsman.org.uk/sites/default/files/ PHSO_Annual_Report_and_Accounts_2017_2018.pdf.

2 National Audit Office. Department of Health and NHS England: investigation into NHS continuing healthcare funding. 5 Jul 2017. https://www.nao.org.uk/wp-content/uploads/ 2017/07/Investigation-into-NHS-continuing-healthcare-funding-1.pdf.

3 Public Accounts Committee. Investigation into NHS continuing healthcare funding. 17 Jan 2018. https://www.parliament.uk/business/committees/committees-a-z/commonsselect/public-accounts-committee/inquiries/parliament-2017/investigation-nhs-healthcarefunding-17-19/.

4 Phillips N. "Our life savings are spent on care that should be free." BBC News 2019 Jun 11. https://www.bbc.co.uk/news/health-48555199.

5 Unia E, Rhodes D. Thousands died waiting for NHS funding decision. BBC News 2018 Aug 24. https://www.bbc.co.uk/news/uk-england-45116453.

6 NHS England. NHS continuing healthcare redress guidance for CCGs. https://www. england.nhs.uk/healthcare/redress-guidance-ccgs/.

7 Parliamentary and Health Service Ombudsman. How we can help with complaints about continuing healthcare funding. https://www.ombudsman.org.uk/making-complaint/whatwe-can-and-cant-help/how-we-can-help-complaints-about-continuing-healthcare-funding.

8 Care to be Different. Frustrated with CCG delays? Here's how to complain. 24 Oct 2018. https://caretobedifferent.co.uk/frustrated-with-ccg-delays-heres-how-to-complain/.

9 Beacon. NHS continuing healthcare. https://www.beaconchc.co.uk/what-is-nhs-continuinghealthcare/.

10 Age UK. Factsheet 20: NHS continuing healthcare and NHS-funded nursing care. Oct 2018. https://www.ageuk.org.uk/globalassets/age-uk/documents/factsheets/fs20 nhs continuing_healthcare_and_nhs-funded_nursing_care_fcs.pdf.
11 Oliver D. David Oliver: NHS continuing care is a mess. BMJ 2016;354:i4214. https://www. bmj.com/content/354/bmj. i4214.10.1136/bmj. 1421427495806

12 Department of Health and Social Care. Care and support statutory guidance. Updated 26 Oct 2018. https://www.gov.uk/government/publications/care-act-statutory-guidance/ care-and-support-statutory-guidance.

13 Carers UK. State of caring report 2019. 8 Jul 2019. https://www.carersuk.org/news-andcampaigns/news/state-of-caring-report-2019.

14 Local Government and Social Care Ombudsman. Social care pressures reflected in Ombudsman's annual review of complaints. 28 Nov 2018. https://www.lgo.org.uk/ information-centre/news/2018/nov/social-care-pressures-reflected-in-ombudsman-sannual-review-of-complaints.

15 King's Fund. More people asking for social care support but fewer getting it as demand leaves social care system at crisis point. 26 Apr 2019. https://www.kingsfund.org.uk/press/ press-releases/social-care-system-crisis-point.

16 King's Fund. Social care 360. 26 Apr 2019. https://www.kingsfund.org.uk/publications/ social-care- 360

17 Department of Health and Social Care. National framework for NHS continuing healthcare and NHS-funded nursing care. 28 Nov 2012. https://www.gov.uk/government/publications/ national-framework-for-nhs-continuing-healthcare-and-nhs-funded-nursing-care.

18 NHS Benchmarking Network 2018 managing frailty \& DToC project-results published. 1 Apr 2019. https://www.nhsbenchmarking.nhs.uk/news/2018-managing-frailty-amp-dtocproject-results-published.

Published by the BMJ Publishing Group Limited. For permission to use (where not already granted under a licence) please go to http://group.bmj.com/group/rights-licensing/ permissions 